\title{
A Survey Analysis on Institutional Challenges in implementing Public Private Partnership (PPP) Projects: A perspective from a developing economy of Ghana.
}

\author{
Mumuni Ishawu ${ }^{1}$, Chen Guangyu², Emelia Darko Adzimah³, Aliu Mohammed Aminu ${ }^{4}$ \\ 1 School of Management and Economics, University of Electronic Science and Technology of China,Chengdu, China, \\ Koforidua Technical University, Koforidua, Ghana. \\ 2 School of Management and Economics, University of Electronic Science and Technology of China,Chengdu, China.

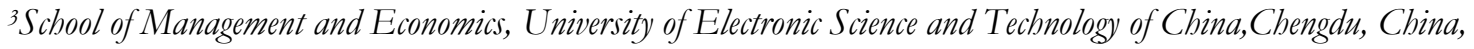 \\ Kumasi Technical University, Kumasi, Ghana. \\ ${ }_{4}^{4}$ chool of Management and Economics, University of Electronic Science and Technology of China,Chengdu, China.
}

\begin{abstract}
There is an increasing demand for infrastructure projects all over the world. One important model adopted in providing them is Public - private partnership. To this end, this study aims at identifying the most influential factors as well as new factors that will serve as barriers against the adoption of PPP as a model in procurement of social projects in Technical Universities in Ghana. Using a survey questionnaire, appropriate data were obtained from Ghanaian Technical Universities. In all, a total of 152 questionnaires were collected from the participants. The research found that 'lack of governmental guidelines and procedures' was perceived as the most important factor with a mean score of 4.12. The remaining four factors in descending order include; 'high risk relying on the public sector, high charge to direct users, very few scheme reach the contract stage and high participation cost. These are depicted with the following mean scores $(4.10,4.02,4.01$ and 3.99 respectively. The factors considered as neither most important nor least important include; less employment positions, lack of experience and appropriate skills, a great deal of management time spent on contract transactions and lengthy delays in negotiations. Interesting enough, the factors that are considered as least important include; excessive restrictions on participations for PPP with a mean score average of 3.67. Also, high project cost and political instability were also perceived as least important. This shows that these two factors were not seen as the same most important hindrances. The results shows that practitioner's (public institutions and private investors) should consider these key factors as barriers to be address for adoption and implementation of a successful achievement of PPP projects.
\end{abstract}

Keywords: Public private partnership; projects; challenges; institutional, developing economy

Citation: Mumuni Ishawu, Chen Guangyu, Emelia Darko Adzimah, Aliu Mohammed Aminu. A Survey Analysis on Institutional Challenges in implementing Public Private Partnership (PPP) Projects: A perspective from a developing economy of Ghana, 2020; 5 (2): 24-35.

Received: April 14, 2020

Accepted: June 30, 20 


\subsection{Introduction}

Countries all over the world are using Public Private Partnership (PPP) model to procure infrastructure projects, including developing countries such as Ghana.(Tingtin, Yan, \& Suzanne, 2016,; Marlies, Koen, Thomas., 2017). This is due to a glaring need for these projects, the investments of which are often large, lumpy, and in capital projects. (Alpana, 2012). The cost of maintaining existing infrastructure and undertaking necessary extensions as well as repairs of its coverage is estimated at seven percent of developing countries' Gross Domestic Product (GDP), equivalent to about 600 billion US dollars (Alpana, 2012).

In developing economy such as Ghana, there is the necessity for practical and skills human resource for Ghana's overall development. This cannot be over emphasized. The Technical and vocational sector is responsible for producing the technical and vocational human skills resource for sustainable national development. Inevitably, the Polytechnics are responsible for producing these graduates (Adomah et al., 2014). In August, 2013, the government of Ghana emphasized that the Polytechnics have the capacity to be transformed into technical universities as they are better equipped than most of the private universities. Moreover, they will be in a better position to train middle level manpower needs of the country which will assist in the development of the nation. There is therefore, the need to improve upon the infrastructure facilities of these technical universities.

The Private finance initiative started in 1992 as PPP procurement model, (HS \& Scott, 2009), and the concept is different from one country to the other, and may also be applied to different sectors of the economy (Kristine, Siril, Espen, \& Jardar, 2016).

Broadly, PPP is describe as "Arrangements whereby private parties participates in, or provide support for, the provision of infrastructure and a PPP project results in a contract for a private entity to deliver public infrastructure - based services"(Grimsey \& Lewis, 2004). Infrastructure in this definition includes capital projects including schools, social housing, hospitals and prisons (Burbury, 2017). The present study intends to follow the above definition.

PPP contracts have become well established instruments for procuring governmental projects, as it incorporate risk sharing, efficiency, and quality, achieving value for money, innovation, experience and private sector funds and breaking the monopoly enjoyed by public sector through infrastructure development (Khalid \& Paul, 2014,; Xueging \& Shu, 2012).

Procuring projects such as staff bungalows, commercial centers, student's dormitories, recreational and sports centers are crucial to the survival of every Technical Universities in the world. Especially in Ghana, where there has been an increasing demands of these projects due to the recent conversion of Ghanaian Polytechnics into Technical Universities (Act, 2016, ACT, 922) as amended by (Act, 2018, ACT 974).

However, the cost of procuring these projects is so huge that, government alone finds it difficult to provide them, and these challenges can be addressed by adopting the PPP model (Zhang, 2005,; Xueging \& Shu, 2013,; Cheung et al., 2009). 
Despite the significance of using PPP model, it has been under studied in the context of public institutions in Ghana and the challenges in procuring infrastructural projects. A limited number of studies have considered it in the area of economic projects such as transportation, telecommunication and power generation. (Osei-Kyei \& Chan, 2017,; Ameyaw, Adjei-Kumi, \& Owusu-Manu, 2015,; Osei-Kyei \& Chan, 2015,: Robert, 2014).

In dealing with the above knowledge gap identified in literature, our study aim at identifying the most influential and new factors that will serve as challenges against the use of PPP as a model in procurement of capital projects in Ghana.

The present study aims at dealing with the following research question:

RQ1. Which of the following will serve as the most influential factors that will become barriers in using PPP as a means of acquiring projects in your institution?

The results of this study will extend to both the practice and research of barriers affecting the use of PPP model in procurement of PPP projects by public institutions in Ghana. In addition, it will also provide valuable information to both government (public institutions) and private international as well as local investors who intends to invest in PPP projects. This will be achieved as a result of being able to ascertain the most relevant factors to be considered.

The next section discusses the related literature for the study; this will be followed by the methodology, then we discussed the survey analysis of the results obtained; we conclude with the managerial implications, limitations and suggestions for further study.

\section{Literature review}

\subsection{Why the need for adopting PPP method of Procurement}

The private sector has always been in co-operation with the public sector for the provision of public infrastructure in the areas of road construction, railways, and buildings as contractors. In terms of consultancy, the private sector has also been very active in the area of consulting for the public sector, (AbdulGaniyu et'al, 2014). However, with population explosions in most developing countries over the last two decades due to improved healthcare technologies, there arose a competition from other sectors of the economy for the meager tax revenue accruing to governments.

Governments in response have sought to seek alternative means of financing the much needed infrastructure while ensuring that it fulfills its other numerous responsibilities to its citizens, hence the move towards PPPs. Therefore, it could be said that the most important reason till date for the adoption of the PPP strategy in both developed and developing countries was solely constraints on government revenue (Almarri, 2017).

Although the practice of PPP or concessions has been used in the past for the Perrier brother's concessions in Paris and the Suez Canal, the rationale for their use then was not espoused or stated. However, in recent years the PPP has been attributed with many positive benefits which include creating a private - sector led economy, 
hastening development, reducing project life - cycle costs, promoting national economic growth and improving national infrastructure. (Krishna, and Husnullah Pangeran, 2010). It is also said to deliver better value for money than the traditional procurement (Duncan, 2004), and aids in the transfer of technology to local enterprises.(Li, Akintoye, Edwards, \& Hardcastle, 2005).

The PPP is also a response to the rising marginal cost of state funded investments in public services imposed by global capital markets (Steven, Mathias, and Darinka, 2011). Most importantly, the PPP has been found to help improve on the management of the twin risks of time and cost overruns better than the traditional procurement method (Peter, 2005).

Furthermore, the PPP has helped countries reduce their bureaucratic burden as staffs are transferred to the private sector once they take over provisions of service in any sector. To this extent, in Malaysia for example, 113,440 staffs have been transferred from the government balance sheets to private sector with an accompanying savings of RM7.79 billion annually on operating expenditure or $\$ 200$ billion in 25 years; and 161 billion in capital expenditure. In the United Kingdom also, over 35,000 staff were transferred to the private sector through PPP deals. (NAO, 2003). The situation however, is not the same in Ghana as there are still challenges with PPP implementations (Osei-Kyei \& Chan, 2017).

The degree to which this procurement strategy has been employed globally, has reached a scale which is big enough to have macroeconomic and systematic significance in a number of countries (Frederic Blanc-, Hug, and Timo, 2009). Despite these espoused benefits of adopting PPP, many African countries and Ghana in particular have found it difficult to make any progress in this respect.

\subsection{Challenges against the adopting PPP method of procurement of social projects}

Although Public Private Partnership projects has been touted as being an efficient tool for infrastructure improvement or development across all sectors, like any concepts, it has it short-comings. Table 1 gives a summary of the barriers / challenges in adopting PPP projects. 
Table 1. Barriers/challenges of PPP projects implementations in Ghana

\begin{tabular}{ll}
\hline NO. & BARRIERS / CHALLENGES \\
\hline 1. & Reduce the project accountability \\
2. & High risk relying on private sector \\
3. & Very few schemes have actually reached the contract stage \\
4. & Political Instability \\
5. & High charge to direct users \\
6. & Less employment positions \\
7. & High participation costs \\
8. & A great deal of management time spent in contract transactions \\
9. & High projects costs \\
10. & Lack of experience and appropriate skills \\
11. & Confusion over government objectives and evaluation criteria \\
12. & Excessive restrictions on participations. \\
13. & Lengthy delays in negotiations \\
14. & Lack of government guidelines and procedures on PPPs \\
15. & Higher risk relying on the public sector \\
16 & Fear of not achieving value for money \\
\hline
\end{tabular}

(Source: Li et al. 2005 and Cheung et al. 2010)

The above challenges was adapted from the works of (Li et al., 2005) and (Regan, Smith, \& Love, 2010)(E, AP, \& S, 2009) which identified 13 challenges or barriers in implementing PPP projects. Three (3) additional challenges or barriers were added to the thirteen negative factors in the original instruments of ( $\mathrm{Li}$ et al. 2005) and (Cheung et al., 2010) making it 16 barriers. (See table 1).

\section{Methodology}

\subsection{Sample and Sampling procedure and collection of data}

The Convenience sampling method was used to select four (4 out of the now 8 technical universities in Ghana. Moreover, the four technical universities include; Accra, Kumasi, Koforidua and Takoradi respectively. The selected regions were chosen because they are the four major public technical universities in Ghana as well as their proximity and ease of collecting data.

The questionnaire consists of two main sections. Section A consists of the Bio data information of the respondents. The second part, (section B) uses the Likert scale to measure the level of importance on the most influential factors in using PPP model to procure infrastructural projects. This was done on a scale of 1 to 5 , where ' 1 ' is least important factor and ' 5 ' being most important factor.

\subsection{Data collection}

The questionnaire survey was distributed to the participants at their various institutions. The participants or respondents include the senior staff members such as, the Vice Chancellors, Pro-Vice Chancellors, Registrars, 
Finance Directors, Directors of Audit, Heads of Procurement and Head of Works department. These people were used because they are directly or indirectly involved with construction projects in their various universities.

A cover letter was attached to the questionnaire to explain the purpose of the study and to assure the participants of the confidentiality of the information provided. 200 questionnaires were administered to the participants, a total of 152 questionnaires were successfully collected representing a response rate of $76 \%$. (See table 2).

\subsection{Data analysis}

The data collected from the questionnaire survey were analyzed using the IBM Statistical Package for Social Sciences (IBM SPSS version 23). The Bio-data of respondents were ascertained, the ANOVA analysis was conducted for the various institutions to obtain their views on the mean scores ranking for both grouped as well as individual institutions on the relative importance of each barrier factor for PPP implementation.

\section{Results and Discussions}

Table 2 below indicates the bio-data on the descriptive statistics of the respondents from four technical universities in Ghana.

Table 2. Descriptive statistics of Bio-data

\begin{tabular}{llll}
\hline Characteristics & Group & Cases & Valid percentage \\
\hline Gender & Male & 95 & 62.5 \\
& Female & 57 & 37.5 \\
Total & 152 & 100 \\
Age & $40-49$ & 51 & 33.6 \\
& $50-59$ & 84 & 55.3 \\
Educational Level & 60 and above & 17 & 11.2 \\
& Total & 152 & 100 \\
& Master's Degree & 44 & 28.9 \\
Name of your Institution & PhD Degree & 73 & 48.0 \\
& Other qualifications & 35 & 23.0 \\
& Total & 152 & 100 \\
& Accra $\quad$ Tech. & 38 & 25.0 \\
& University & 38 & 25.0 \\
& Koforidua Tech. & 40 & 26.3 \\
& Univ. & 36 & 23.7 \\
& Kumasi Tech. Univ. & 152 & 100 \\
& Takoradi Tech. & & \\
& Univ. & & 2.6 \\
Your position in your Institution & Total Chice Chancellor & 4 & 2.6 \\
& Pro-Vice Chancellor & 4 & 2.6 \\
& Registrar & 4 & 2.6 \\
& Finance Director & 4 & 2.6 \\
& Director & 4 & 2.6 \\
& Procurement. & 4 & 78.9 \\
\hline & Director of Works. & 4 &
\end{tabular}




\begin{tabular}{llll}
\hline & Heads of Dep't. & 152 & 100 \\
Total & & 13.8 \\
Less than 2 years & 21 & 27.0 \\
$2-5$ years & 41 & 59.2 \\
5 years and & 90 & 100 \\
above & 152 & \\
Total & & \\
\hline
\end{tabular}

In total, 152 questionnaires were analyzed, out of a total of 200 administered to senior staff members of technical universities in Ghana. This represents $76 \%$ of response rate. In terms of educational level, 7 represents the master's degree level with a mean statistics of 5.63 and a variance statistics and skewness level of 0.837 and -.215 respectively. The age range of the respondents represents the maximum statistics of 7 which is 42 and above. This indicates that most of the respondents are older enough. The mean statistics of the respondent's age is 5.94. A variance of 0.618 and skewness level of 0.22 makes it statistically acceptable. In terms of the kurtosis, $0.207,-.732$ and -1.187 respectively was recorded for gender, educational level and age.

Table 3. Results for mean scores and ranking for institutional barriers

\begin{tabular}{|c|c|c|c|c|c|c|c|c|}
\hline \multirow{2}{*}{$\begin{array}{lr}\text { Challenges } & \text { of } \\
\text { PPP } & \text { Social } \\
\text { Projects } & \end{array}$} & \multicolumn{2}{|c|}{ Accra Tech. Uni. } & \multicolumn{2}{|c|}{ K'dua Tech. Uni. } & \multirow{2}{*}{$\begin{array}{l}\text { Kumasi } \\
\text { Uni. } \\
\text { Mean }\end{array}$} & \multirow{2}{*}{$\begin{array}{l}\text { Tech. } \\
\text { Rank }\end{array}$} & \multirow{2}{*}{$\begin{array}{l}\text { Takoradi } \\
\text { Uni. } \\
\text { Mean }\end{array}$} & \multirow{2}{*}{$\begin{array}{l}\text { Tech. } \\
\text { Rank }\end{array}$} \\
\hline & Mean & Rank & Mean & Rank & & & & \\
\hline $\begin{array}{l}\text { Lack gov't } \\
\text { guidelines and } \\
\text { procedures }\end{array}$ & 4.08 & 1 & 4.18 & 1 & 4.23 & 1 & 4.00 & 5 \\
\hline $\begin{array}{l}\text { Lengthy delays in } \\
\text { negotiations }\end{array}$ & 3.89 & 5 & 3.95 & 3 & 3.95 & 7 & 3.89 & 8 \\
\hline $\begin{array}{l}\text { Excessive } \\
\text { restrictions on } \\
\text { participations }\end{array}$ & 3.66 & 10 & 3.76 & 9 & 3.68 & 11 & 3.56 & 12 \\
\hline $\begin{array}{l}\text { Confusion over } \\
\text { gov't objectives } \\
\text { and evaluation } \\
\text { criteria }\end{array}$ & 3.74 & 8 & 3.68 & 10 & 3.83 & 9 & 3.94 & 7 \\
\hline $\begin{array}{l}\text { A great deal of } \\
\text { mag't time spent } \\
\text { on contract } \\
\text { transactions }\end{array}$ & 4.08 & 1 & 3.89 & 5 & 4.03 & 6 & 3.69 & 11 \\
\hline $\begin{array}{c}\text { Lack of experience } \\
\text { and appropriate } \\
\text { skills }\end{array}$ & 3.97 & 4 & 3.82 & 7 & 3.95 & 7 & 3.97 & 6 \\
\hline High project cost & 3.68 & 9 & 3.84 & 6 & 3.70 & 10 & 3.83 & 9 \\
\hline $\begin{array}{l}\text { High participation } \\
\text { cost }\end{array}$ & 4.05 & 2 & 3.82 & 7 & 3.95 & 7 & 4.14 & 2 \\
\hline $\begin{array}{l}\text { Less employment } \\
\text { positions }\end{array}$ & 3.79 & 7 & 3.79 & 8 & 4.18 & 2 & 4.11 & 3 \\
\hline $\begin{array}{c}\text { Fear of not } \\
\text { achieving value for } \\
\text { money }\end{array}$ & 3.84 & 6 & 3.68 & 10 & 3.45 & 13 & 3.78 & 10 \\
\hline
\end{tabular}




\begin{tabular}{ccccccccc}
\hline $\begin{array}{c}\text { High charge to } \\
\text { direct users }\end{array}$ & 4.03 & 3 & 3.92 & 4 & 4.15 & 3 & 3.97 & 6 \\
$\begin{array}{c}\text { Political instability } \\
\text { Very few scheme } \\
\text { have actually } \\
\text { reached the } \\
\text { contract stage. }\end{array}$ & 3.79 & 7 & 3.45 & 11 & 3.90 & 8 & 4.06 & 4 \\
$\begin{array}{c}\text { High risk relying } \\
\text { on the public } \\
\text { sector }\end{array}$ & 4.03 & 4 & & 1 & 4.08 & 4 & 3.78 & 10 \\
$\begin{array}{c}\text { High risk relying } \\
\text { on the private } \\
\text { sector }\end{array}$ & 3.84 & 3 & 4.08 & 2 & 4.05 & 5 & 4.25 & 1 \\
$\begin{array}{c}\text { Reduce the project } \\
\text { accountability }\end{array}$ & 3.74 & 6 & 3.79 & 8 & 3.95 & 7 & 3.94 & 7 \\
\hline
\end{tabular}

\subsection{Results of PPP Barriers for grouped mean scores}

As shown in table 3 above, the mean scores for the sixteen factors ranging from 3.80 to 4.51 , which indicates that most of the factors are of different importance as perceived by the overall respondents as the barriers for successful implementation of PPP projects in Ghana. The following sub-section discusses the results of the overall respondents. This is depicted in table 4 below.

Table 4. Grouped means scores of PPP projects implementations in Ghana

\begin{tabular}{clcr}
\hline \multicolumn{2}{c}{ NO. } & \multicolumn{1}{c}{ BARRIERS / CHALLENGES } & MEAN SCORE \\
RANK & & 10 \\
\hline 1. & Reduce the project accountability & 3.82 & 2 \\
2. & High risk relying on public sector & 4.10 & 4 \\
3. & Very few schemes have actually reached the contract stage & 4.01 & 11 \\
4. & Political Instability & 3.80 & 3 \\
5. & High charge to direct users & 4.02 & 6 \\
6. & Less employment positions & 3.97 & 5 \\
7. & High participation costs & 3.99 & 7 \\
8. & A great deal of management time spent in contract transactions & 3.93 & 12 \\
9. & High projects costs & 3.76 & 7 \\
10. & Lack of experience and appropriate skills & 3.93 & 11 \\
11. & Confusion over government objectives and evaluation criteria & 3.80 & 14 \\
12. & Excessive restrictions on participations. & 3.67 & 8 \\
13. & Lengthy delays in negotiations & 3.92 & 1 \\
14. & Lack of government guidelines and procedures on PPPs & 4.12 & 9 \\
15. & Higher risk relying on the private sector & 3.88 \\
16 & Fear of not achieving value for money & 3.68 & 13 \\
& & & \\
\hline
\end{tabular}

Table 4 above depicts the top 5 factors that were perceived as the most important in implementing PPP projects in Ghana. Out of the five, 'lack of government guidelines and procedures' was perceived as the most important with 
a mean score of 4.12. The remaining four factors in descending order include; 'high risk relying on the public sector, high charge to direct users, fear of failure because very few scheme have actually reached the contract stage and high participation cost. These are depicted with the following mean scores (4.10, 4.02, 4.01 and 3.99 respectively.

The factors considered as neither most important nor least important include; less employment positions, lack of experience and appropriate skills, a great deal of management time spent on contract transactions and lengthy delays in negotiations. Interesting enough, the factors that are considered as least important include; excessive restrictions on participations for PPP with a mean score average of 3.67. This is in sharp contrast to that of the work of (Ismail \& Harris, 2014). Also, fear of not achieving value for money, high project cost and political instability were also perceived as least important. These were depicted with the mean average scores of 3.67, 3.68, 3.76 and 3.80 respectively.

The factor 'reduce project accountability' (mean $=3.80$ ) is the $10^{\text {th }}$ most important factor that hinders the implementation of PPP projects in Ghanaian Technical Universities. This evidence needs to be addressed carefully, because is based on the fact that there have been some PPP projects that were not successful in the other sectors of the Ghanaian economy. This led to the inability of these projects to be unaccounted for and became a waste of the countries resources. Also, the Ghanaian economy is still experiencing the problem of corruption by public officials and as a result, many government projects are not properly accounted for. The lack of 'reduce project accountability' will also result in a reduction in project quality and an increase in the cost of the PPP project (Beh, 2010).

The $5^{\text {th }}$ most important factors that hinders the adoption of PPP by Ghanaian Technical Universities is 'high participation cost' ( mean $=3.82$ ), and 'Lack of experience and appropriate skills', is the $7^{\text {th }}$ most important factor with a (mean $=3.82$ ). These two factors share the same mean scores. In terms of the 'high participation costs', this means, the cost involved in taking part in PPP tender negotiations process is also an important factor. This is also a sharp contrast to the works of (Suhaiza and Fatima, 2014), (Abd Karim, 2011), (Li et al., 2005) and (Cheung, Chan, Lam, Chan, \& Ke, 2012). They found out that 'lengthy delays in negotiation processes' is the second most important factor in their various works.

The $6^{\text {th }}$ most important factor serving as a challenge for implementing PPP social projects in Ghanaian Technical Universities is 'less employment positions', (mean = 3.91). This factor has also become important because the Ghanaian economy is saddled with the problem of unemployment and therefore any project that will not yield huge employment opportunities is seen as a hindrance. In contrast, studies by ( $\mathrm{Li}$ et al., 2005; Cheung et al, 2010) reported that this factor was not ranked highly in the United Kingdom and Hong Kong respectively as compared to Ghana. They were ranked last and twelfth by the respondents from Hong Kong and the United Kingdom respectively. Political instability was among the least ranked as the $\left(11^{\text {th }}\right)$ position. This may be due to the fact that Ghana has relatively been peaceful since returning to the fourth republic in 1992, with successfully exchanging of political power to the two main political parties (NPP AND NDC). 
Moreover, two additional factors that were introduced in this study 'fear of not achieving value for money and higher risk relying by the public sector were ranked separately. Whereas fear of not achieving value for money was ranked lowly $\left(13^{\text {th }}\right)$, higher risk relying on the public sector was ranked as an important factor $\left(2^{\text {nd }}\right)$. This shows that these two factors were seen differently.

\section{Conclusions, Limitations and directions for future research}

Our research examines relationships between institutional challenges in implementing PPP projects, using Technical Universities in Ghana as the study area. The article identified 16 challenges in implementing PPP projects in Ghana.

The findings of the present study did not only add up to the limited knowledge in this field as PPP implementation is relatively new and limited in Ghana, but, to some extent, also contribute to practice. Most in particular, understanding the barriers or constraints factors for adoption of PPP allows relevant parties (either the government or private sector consortiums) to take the necessary measures as an effort in overcoming the identified constraints to ensure maximum benefits is achieved from the PPP projects.

Most importantly, the findings on 'reduce project accountability' provides a signal to the government to strengthen the PPP regulatory body to play a more effective role in resolving this matter to ensure maximum benefits is achieved from the PPP projects.

In addition, the government needs to clearly state the objectives of promoting PPP as a means of financing social projects in Ghanaian technical universities by sharpening the skills and experiences of private sector consortiums and agencies interested in investing in PPP projects. This can be achieved through attending conferences, seminars and short courses.

This study is not without limitations, first the sample consist of only participants from the public institutions. It will be constructive for future studies to include respondents from the private sector consortiums or private sector institutions.

Also, this study uses questionnaire survey by limiting it only to the technical universities without considering the other tertiary institutions in Ghana. Also, other sectors of the Ghanaian economy such as roads and transport, telecommunications and health were not considered.

Future studies may consider using qualitative instruments like interviews or open ended questions, which have access to rich and detailed sources of qualitative variations. There might be other important barriers that are considered to be important and valuable for PPP implementation. Therefore, generalization of the research findings should be done with caution. Furthermore, future studies should not only consider other sectors of the Ghanaian economy but also engage in comparative studies with other developed or developing economy.

In conclusion, despite the limitations, this study offers some relevance concerning the perceptions of the public sector institutional challenges or barriers of PPP projects. 


\section{References}

1. Abd Karim, N. . (2011). No Title Risk allocation in public-private partnership (PPP) project: A review on risk factors. International Journal of Sustainable Construction Engineering \& Technology, 2(2), 8-16.

2. Abdul Ganiyu, O., Abdullai, A. U., Noor Amila, W. A. Z., Mahmoud, S., \& Dabo, B. H. (2014). Slow adoption of PPPs in developing countries: Survey of Nigerian Construction professionals. Fourth International Symposium on Infrastructure Engineering in Developing Countries, IEDC 2013, 188-195. AbujaNigeria.

3. Adomah.,B., Kyeremah., F., Emmanuel., F. (2014. Transition from Polytechnic to Technical Umiversities; The role of Sunyani Polytechnic Library. International Conference on Applied Science and Technology (ICAST, 2014.

4. Almarri, K. (2017). The influence of critical success factors on value for money viability analysis in publicprivate partnership projects. Project Management Journal, 48(4), 93-106.

5. Alpana, K. (2012). Building infrastructure: Private participation in emerging economies. Procedia- Social and Behavioral Sciences, 37, 368-378.

6. Ameyaw, C., Adjei-Kumi, T., \& Owusu-Manu, D. (2015). Exploring Value for money (Vfm) assessment methods of public - private partnership projects in Ghana. A theoretical framework. Journal of Financial Management of Property and Construction., 20(3).

7. Beh, L. (2010). No TitleDevelopment and distortion of Malaysian Public private partnerships partronage, privitised profits and pitfalls. The Australian Journal of Public Addministration, 69(S1), S74-S84.

8. Cheung, E., Chan, A. P., Lam, P. T., Chan, D. W., \& Ke.Y. (2012). A comparative study of critical success factors for public private partnerships (PPP) between Mainland China and the Hong Kong Special Administrative Region. Facilities, 30(13), 647-666.

9. Cheung, E.,Chan, AP., \& Kajawski, S. (2009). Framework for the performance measurement of publicprivate partnerships. Journal of Infrastructure Systems, 21(1).

10. Grimsey, D., \& Lewis, M. K. (2004). Public Private Partnership: The worldwide Revolution in Infrastructure Provision and Project Finance. Cheltenham, UK.: Edward Elgar Publishing.

11. HS, R., \& Scott, J. (2009). Service delivery and performance monitoring in PFI/PPP projects. Construction Management and Economics, 27(2), 181-197.

12. Khalid, A., \& Paul, B. (2014). Improving risk sharing and investment appraisal for PPP procurement success in large green projects. Social and Behavioural Sciences, 119, 847-856.

13. Kristine, T., Siril, V., Espen, S., \& Jardar, L. (2016). Public-Private Partnership: Transaction Costs of Tendering. International Conference on Project Management. https://doi.org/5-7, 2016.

14. Li, B., Akintoye, A., Edwards, P. J., \& Hardcastle, C. (2005). The allocation of risk in PPP/PFI construction projects in the UK. International Journal of Project Management, 23(1), 25-35.

15. Marlies., H., Koen., V., Thomas., B. (2017). Governing public-private partnership for sustainability An analysis of procurement and governance practices of PPP infrastructure projeccts. International Journal of Project Management, (35), 1184-1195.

16. Osei-Kyei, R., \& Chan, A. (2015). Review of Studies on the critical success factors for public private partnership (PPP) projects from 1990 to 2013No Title. International Journal of Project Management, 33(6), 1335-1346.

17. Osei-Kyei, R., \& Chan, A. P. (2017). Implementing public-private partnership (PPP) policy for public construction projects in Ghana: Critical Success factors and policy implications. International Journal of Construction Management, 17(2), 113-123.

18. Osei-Kyei, Robert, A., A, D., \& JK, O.-K. (2014). Reasons for adopting public-private partnership (PPP) for construction projects in Ghana. No Title. International Journal of Construction Management, 14(4), 227-238.

19. Regan, M., Smith, J., \& Love, P. . (2010). Impact of the capital market collapse on public-private partnership infrastructure projects. Journal of Construction Engineering Management, 137, 6-16.

20. Ismail, S., \& Harris, F. A. (2014). Challenges in implementin Public private partnership in Malaysia. International Conference on Accounting Studies, ICAS, 5-10. Kuala Lumpur, Malaysia.

21. Tingtin, L., Yan, W., \& Suzanne, W. (2016). Identifying Critical factors affecting the effectiveness and efficiency of tendering processes in Public- Private Partnerships (PPPs): A Comparative analysis of Australia and China. International Journal of Project Management, 34, 701-716.

22. Xueging, Z., \& Shu, C. (2012). A systematic framework for infrastructure development through public private partnership. International Association of Traffic and Safety Sciences Research, 36, 88-98. 
23. Xueging, Z., \& Shu, C. (2013). A systematic framework for infrastructure development through public private partnership. International Association of Traffic and Safety Sciences Research, 36, 88-98.

24. Zhang, X. Q. (2005). Critical success factors for public-private parnerships in infrastructure development. Journal of Construction and Engineering Management, 131(1), 3-14. 